\title{
Wood anatomy of the Euphorbiaceae, in particular of the subfamily Phyllanthoideae
}

\author{
ALBERTA M. W. MENNEGA \\ Institute of Systematic Botany, Rijksuniversiteit, Utrecht, The Netherlands
}

Received June 1986, accepted for Publication September 1986

MENNEGA, ALBERTA, M. W., 1987. Wood anatomy of the Euphorbiacene, in particular of the subfamily Phyllanthoideae. The great variety in wood structure of the large family Euphorbiaceae makes it impossible to describe briefly a general wood pattern. Nevertheless, a more or less clear division into four anatomical groups can be made.

A short overview is given of the wood structure of the uni-ovulate subfamilies Acalyphoideae, Crotonoideae, and Euphorbioideae, following the classification by Webster. These subfamilies cannot be distinguished by their anatomy. The paper is mainly devoted to the bi-ovulate subfamily Phyllanthoideae. Within this subfamily, two groups can be recognized on the basis of their wood anatomy: the Aporusa type with a great number of primitive characters, and the Glochidion type, in which primitive features such as scalariform vessel perforation plates are absent. A short description of the 13 tribes is given as well as suggestions for rearrangement of the succession of the tribes. In several tribes some taxa are anomalous and, on anatomical evidence, exclusion of some genera, sometimes with assignment to another tribe, is suggested.

ADDITIONAL KEY WORDS:-Fibre types - parenchyma - Stilaginaceae - Uapacaceae.

\section{CONTENTS}

Introduction . . . . . . . . . . . . . . . . . . . 112

Material . . . . . . . . . . . . . . . . . . . . 112

Characters used for establishing an evolutionary grouping of the

tribes in the subfamily Phyllanthoideae . . . . . . . . . . . . 112

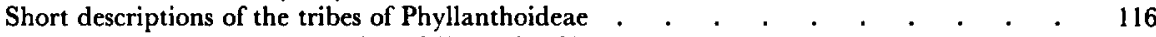

Tribe 8. Aporuseac (Lindl. ex Miq.) Airy Shaw . . . . . . . . . 116

Tribe 7. Antidesmeae (Endl.) Hurusawa . . . . . . . . . . . . . . . . 116

Tribe 9. Drypeteae (Griseb.) Hurusawa . . . . . . . . . . . 117

Tribe 1. Wielandieae Baill. ex Hurusawa . . . . . . . . . . . . . 118

Tribe 2. Amanoeae (Pax \& Hoffm.) Webster . . . . . . . . . . . . $\quad$. 119

Tribe 6. Spondianthea Webster .

Tribe 3. Bridelieac Muell. Arg. . . . . . . . . . . . . . . 121

Tribe 11. Hymenocardieae (Muell. Arg.) Hutch. . . . . . . . . . 121

Tribe 13. Bischofieae (Muell. Arg.) Hurusawa . . . . . . . . . 122

Tribe 4. Dicoelieae Hurusawa . . . . . . . . . . . . . . 122

Table 5. Poranthereae (Muell. Arg.) Grüning . . . . . . . . . . . 122

Tribe 10. Phyllantheae Dumort. . . . . . . . . . . . . . . 122

Tribe 12. Uapaceae (Muell. Arg.) Hutch. . . . . . . . . . . . 124

Conclusions . . . . . . . . . . . . . . . . . . . . . . . . . 124

Acknowledgements . . . . . . . . . . . . . . . . . . . . . . . .

References. . . . . . . . . . . . . . . . . . . . . 125 


\section{INTRODUCTION}

The large family Euphorbiaceae includes a great number of woody taxa, shrubs, trees, a few lianas, and some plants with an unusual habit, like the candelabra Euphorbias or the ericoid Clutia. The wood structure also shows a great variation. It is impossible to present a general diagnosis of an euphorbiaceous wood. However, at least three, perhaps four types of wood can be distinguished. Metcalfe \& Chalk (1950), in the Anatomy of the Dicotyledons, recognized three types in the subfamily Phyllanthoideae: the Aporusa type, the Glochidion type, and a group of taxa designated "other genera"; in the subfamily Crotonoideae the structure is far more uniform, but different from the structure in Phyllanthoideae. In recent years new taxonomic treatments have been published, including those of Hutchinson (1969) and Webster (1975). The latter system is followed in the present paper, because the proposed classification of genera agrees better with the wood anatomical data than that of Hutchinson. Webster recognizes five subfamilies: Phyllanthoideae and Oldfieldioideae (comprising all the bi-ovulate genera), while the uni-ovulate genera are placed in Acalyphoideae, Crotonoideae and Euphorbioideae. With some exceptions (among others, Acalypha, Clutia, Pogonophora) the basic pattern of the wood is alike in the genera belonging to the three last-mentioned subfamilies. It is characterized by absence of scalariform vessel perforation plates; presence of medium to very large intervascular pitting, and similar vessel/ray pitting; presence of apotracheal diffuse or banded parenchyma; numerous narrow, heterocellular rays, often vertically fused; and non-septate, often wide and thinwalled fibres.

The subfamily Oldfieldioideae, comprising most of the "other genera" mentioned above, is not treated in the present paper because this has been studied extensively by Hayden (1980).

In this paper short descriptions are given of the tribes of the Phyllanthoideae composed as in Webster's Conspectus, but arranged in a different order, entirely based on the results of wood anatomy. The results are summarized in Table 1 . In most tribes one or more genera did not seem well placed; sometimes a suggestion has been made for a better positioning, but sometimes this was not possible.

\section{MATERIAL}

The part of this paper dealing with the anatomy of the subfamily Phyllanthoideae is based on examination of slides and macerations of 141 specimens of 116 species and 35 genera. The information on the subfamilies Acalyphoideae, Crotonoideae and Euphorbioideae is founded on data from, respectively, 45, 39 and 17 genera.

The slides are housed in the Wood Anatomy Section of the Institute of Systematic Botany, University of Utrecht. Full details may be obtained on application to the author.

\section{CHARACTERS USED FOR ESTABLISHING AN EVOLUTIONARY GROUPING OF THE TRIBES IN THE SUBFAMILY PHYLLANTHOIDEAE}

The sequence of the tribes in the descriptive section, and as shown in Table 1, is entirely based on wood characters that may be considered as having a definite 
Table 1. Subfamily Phyllanthoideae Aschers. A suggested rearrangement of Webster's tribes based on wood anatomical data

\begin{tabular}{llrl}
\hline & Aporusa type & & Glochidion type \\
\hline 8. & Aporuseae & 6. & Spondiantheae \\
& Didymocistus excepted & 3. & Bridelieae \\
& Martretia included & 11. & Hymenocardieae \\
7. & Antidesmeae & 13. & Bischofieae \\
& Antidesma excepted & 4. & Dicoelieae \\
9. & Drypeteae & 5. & Poranthereae \\
& Paradrypetes included & 10. & Phyllantheae \\
1. $\quad$ Wielandieae & A. Securineginae \\
& Astrocasia excepted & B. & Flueggeinae \\
& Discocarpus excepted & & \\
Actephila included & & \\
2. Amanoeae & & \\
\hline & Actephila excepted & & \\
\hline
\end{tabular}

Place of tribe Poranthereae dubious.

Position of the genera Antidesma, Astrocasia, Didymocistus, Discocarpus, Jablonskia, and Uapaca (tribe 12. Uapaceae) undecided.

relation to phylogeny. Particularly in the case of the Phyllanthoideae, these features are evident in the vessels, the fibres and the parenchyma. In Table 2 the important characters of the vessels of all genera investigated are summarized. The most primitive type of wood shows vessels with scalariform perforation plates, long vessel elements, medium to large intervascular pitting and similar vessel/ray pitting; long, thick-walled, non-septate fibres with bordered pits on the tangential as well as the radial walls, and parenchyma in diffuse strands, or in short irregular bands one cell wide. (For the theoretical underlying principles the reader is referred to Chalk, 1983.) Slightly more advanced genera are considered to be those in which some of the vessel perforation plates are scalariform and others simple, in combination with very fine intervascular pitting. The next group comprises taxa with simple perforation plates and medium to large intervascular pits, with and without parenchyma; the fibres are septate or not. The combination of characters considered most advanced includes vessels with simple perforation plates, medium-sized vessel elements, small intervascular and vessel/ray pitting, absence of parenchyma or some paratracheal parenchyma, and septate fibres.

It is worth noting that often in tribes where most of the genera show diffuse or short bands of parenchyma and non-septate fibres one genus seems out of place by the absence of parenchyma and presence of septate fibres.

Several of the genera with the Aporusa type of wood structure have a special type of fibre wall thickening, first described by Bamber (1974). He noted two types in the subfamily Phyllanthoideae sensu Pax: type I with normal thickening of the walls, type II with very thick walls completely occluding the lumen, and showing abnormal birefringence. In some genera all fibres are of type II, in this paper referred to as Bamber type II; in others, both types occur, as in Actephila (see Fig. 4). Apart from the Phyllanthoideae, Bamber type II also occurs in some genera of the Oldfieldioideae, but not in the other three subfamilies, with the possible exception of Pogonophora (Giraud, 1983). 


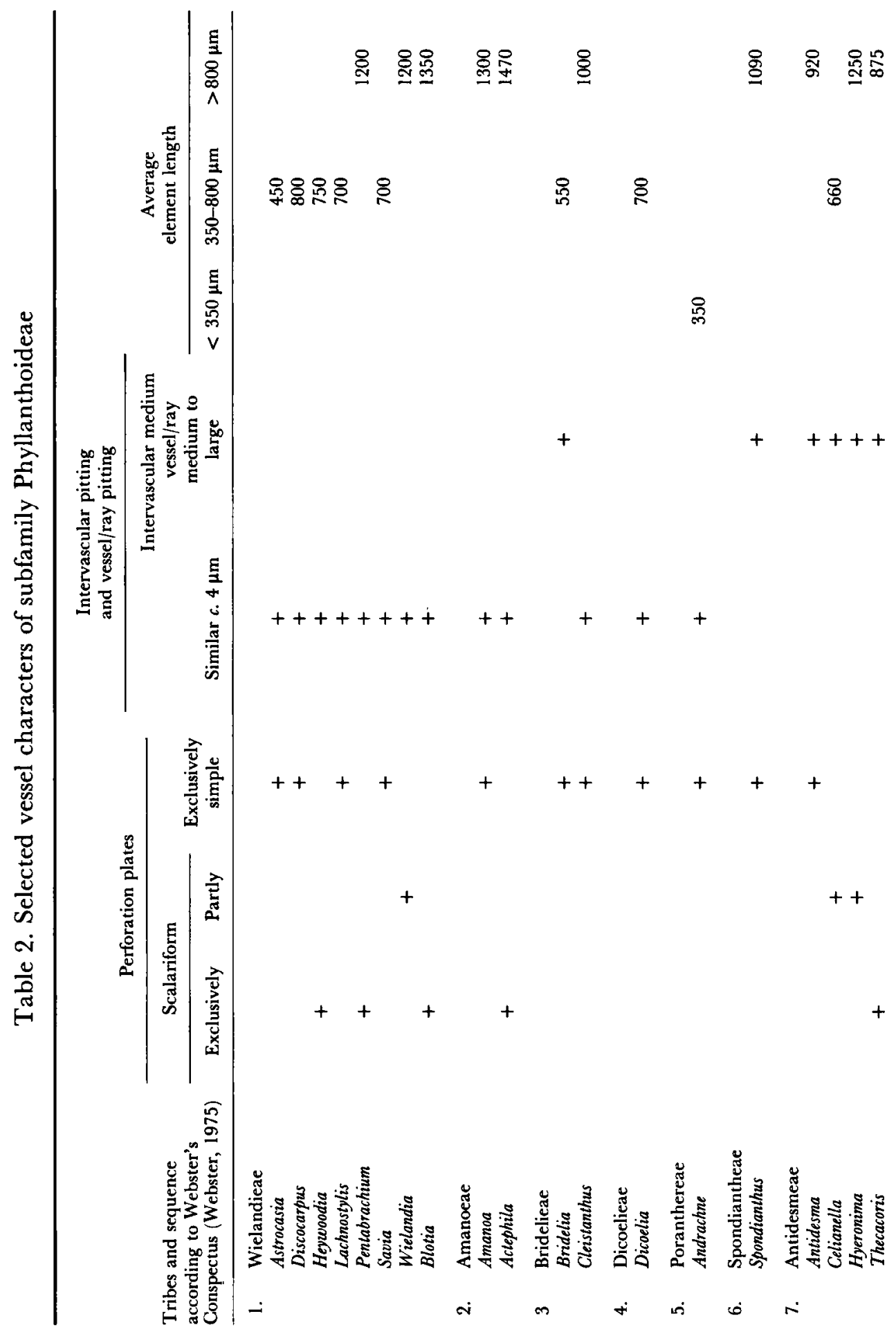




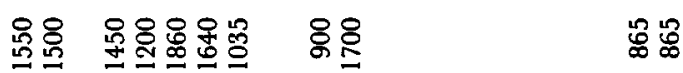

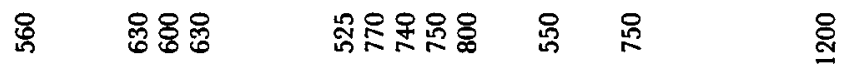
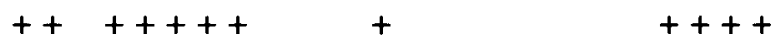

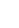

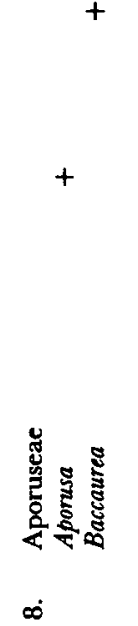

$\infty$
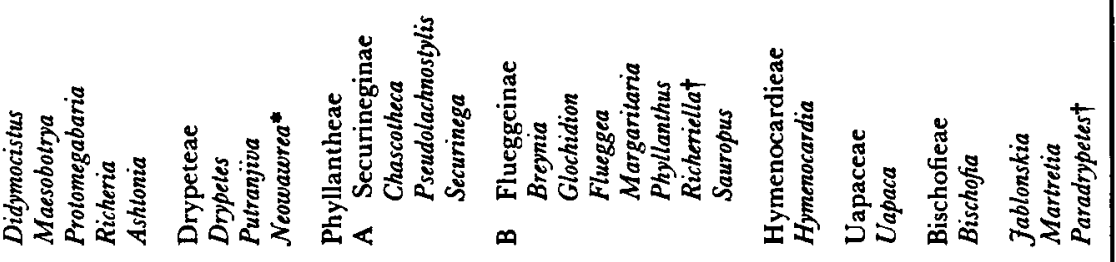

i

$\dot{0}$

$\dot{9}$

i 
Another feature of the fibres in Euphorbiaceae in general is the frequent occurrence of gelatinous walls, but this character has no relation to phylogeny.

Characters of the rays have not been used in establishing a phylogenetic order because they are all rather similar, and of a primitive type.

\section{SHORT DESCRIPTIONS OF THE TRIBES OF PHYLLANTHOIDEAE}

The first five tribes to be described all belong to group A, the Aporusa type of Metcalfe \& Chalk (1950). This type is mainly characterized by scalariform perforation plates in all or at least part of the vessels, long vessel elements, presence of parenchyma in diffuse strands or in short, narrow, irregular bands, non-septate, long and thick-walled fibres, and wide, high, heterogeneous rays (Figs 1-3).

\section{Tribe 8. Aporuseae (Lindl. ex Miq.) Airy Shaw}

The tribe comprises 7 genera, all represented by wood samples (Figs 1-3). vEsSELS with partly scalariform, partly simple perforation plates; vessel elements very long, 1-2 mm; intervascular pitting medium-sized, the vessel/ray pitting similar or larger. PARENCHYMA in diffuse strands or in short, scattered bands one cell wide; strands of 8-14 cells. RAys uniseriate and multiseriate, (2-)6(-9) cells wide, the multiseriate part composed of many rows of procumbent cells, the extensions usually very high; total height $2-8 \mathrm{~mm}$; sheath cells often present. FIBRES very thick-walled, Bamber type II, except in Protomegabaria and Didymocistus, non-septate, large bordered pits on radial and tangential walls; mean length $2900 \mu \mathrm{m}$.

The wood structure of the genera is remarkably similar, with the exception of Didymocistus. In this monotypic genus parenchyma is absent, fibres are thinwalled, wide, and partly septate, scalariform vessel perforation plates are rare.

\section{Tribe 7. Antidesmeae (Endl.) Hurusawa}

The tribe consists of 5 genera; wood samples were available for Antidesma and Hyeronima, but only pieces of twigs of Celianella and Thecacoris.

vessec perforation plates, partly scalariform, partly simple, but in Antidesma exclusively simple, element length on average $900 \mu \mathrm{m}$; intervascular pitting 5-7 $\mu \mathrm{m}$; the vessel/ray pitting moderately large to large, oval, often elongate, in scalariform arrangement. PARENCHYMa as isolated strands, or in short, diffuse bands one cell wide; In Antidesma exclusively scarce paratracheal, and absent in Celianella. RAYs uniseriate and multiseriate, 2-4 cells wide, the middle part very high, often composed of mixed procumbent and square cells, the extensions of tall erect cells moderately to very high, vertically fused rays frequent; height up to $5 \mathrm{~mm}$. FIBRES non-septate in Hyeronima and Thecacoris, partly septate in Antidesma and Celianella; thick-walled, with bordered pits in Hyeronima; thinwalled and often gelatinous in Antidesma and Celianella; simple pits on radial walls; mean length $1760 \mu \mathrm{m}$.

This tribe is not homogeneous in its structure. Celianella shows the same type of structure as Didymocistus regarding the absence of parenchyma and the occasional septate thin-walled fibres of moderate length. Antidesma shares the 

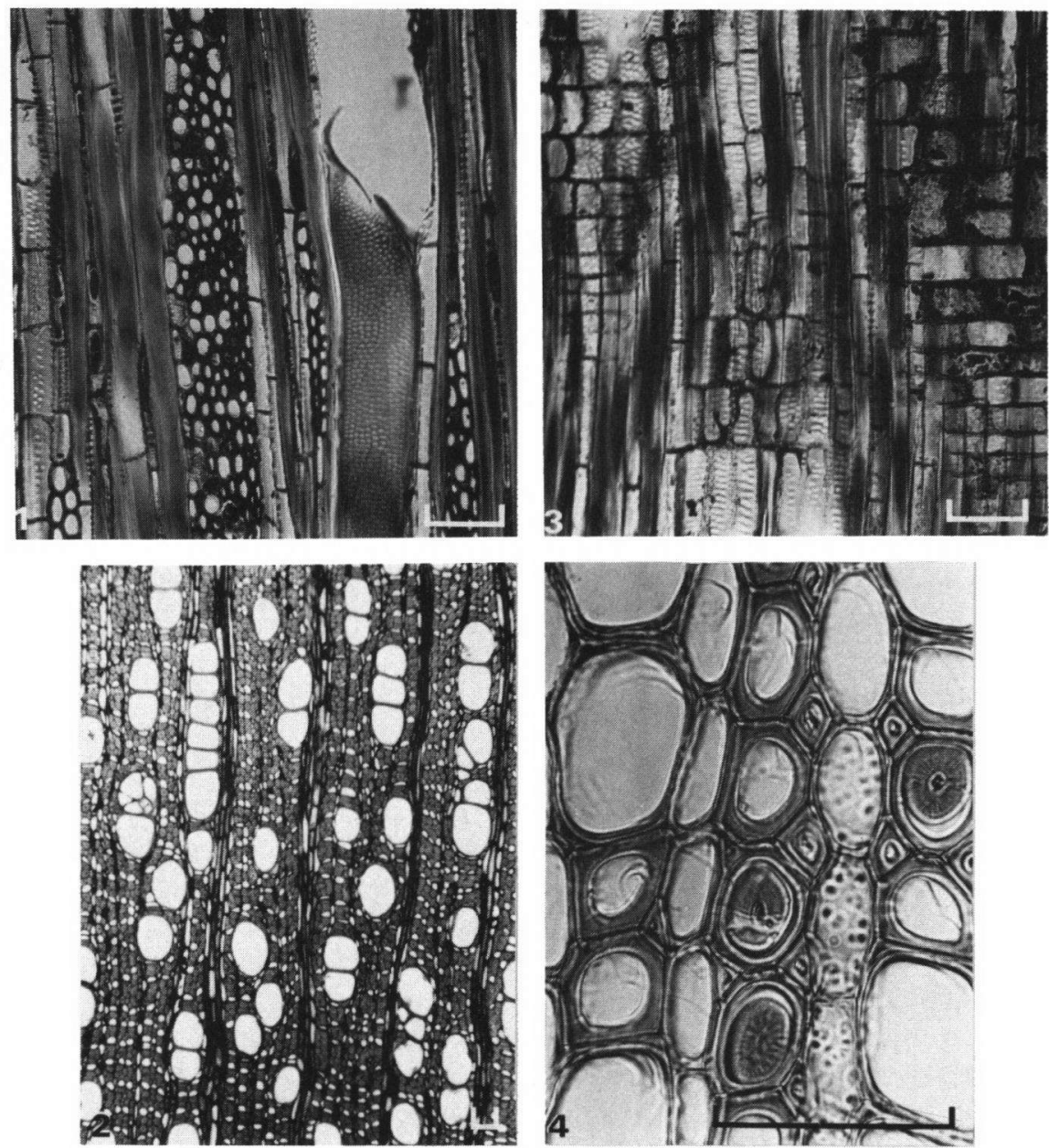

Figures 1-4. Fig. 1. Aporusa microcalyx tangential section showing a wide ray, a vessel with mediumsized intervascular pitting, part of a parenchyma strand with large pits. Fig. 2. Cross-section of A. microcalyx showing vessel grouping and fine irregular bands of parenchyma. Fig. 3. Radial section of $A$. microcalyx showing the large vessel/ray pitting. Fig. 4. Actephila excelsa showing normal thickwalled fibres, and three fibres with occluded lumen, Bamber's type II. Scale bars $=100 \mu \mathrm{m}$.

thin-walled, septate fibres with the foregoing genera, but it also lacks scalariform perforation plates. In Metcalfe \& Chalk (1950), Antidesma was placed in group B with Glochidion-type of wood, associated with Hymenocardia and Aporosella. The wood shows affinities with Spondianthus (tribe 6, Spondiantheae) but also with Bischofia (tribe 13, Bischofieae). Antidesma is one of the genera of doubtful taxonomic position: Airy Shaw (1965) transferred it to the family Stilaginaceae, suggesting affinities with Icacinaceae. Such an affinity is not expressed in the wood anatomy. To me the wood structure fits well with Phyllanthoideae, but perhaps it should be placed in a tribe by itself.

\section{Tribe 9. Drypeteae (Griseb.) Hurusawa}

In Webster's classification the tribe comprises Drypetes, Neowawrea, and Putranjiva. No wood of Neowawrea was available to me, but from the extensive 
treatment by Hayden \& Brandt (1984) of the genus, I am convinced that it was wrongly assigned to this tribe. I agree with their conclusion that it should be placed in subtribe 10B, Flueggeinae.

VESSEL perforation plates partly simple, partly scalariform. Vessel element length (770-)900(-2000) $\mu \mathrm{m}$; intervascular pitting minute, 3-4 $\mu \mathrm{m}$, the ray/vessel pitting similar. PARENCHYMA apotracheal in numerous short, often interrupted bands one cell wide; strands of 6-14 cells. RAYs uniseriate and multiseriate, 2-3 cells wide, the wide part often very high, and the uniseriate extensions also high; vertically fused rays frequent; height from 1.5 to $4 \mathrm{~mm}$. FIBREs non-septate, very thick-walled, Bamber type II; small pits on radial walls, length $1575-3000 \mu \mathrm{m}$.

Drypetes and Putranjiva are anatomically similar. Some species of Drypetes show a marked resemblance to species of Wielandia and Heywoodia. The wood structure of Paradrypetes Kuhlm. is, according to descriptions by Milanez (1935) and by Matos Araujo \& Mattos Filho (1984), almost identical to that of Drypetes, except for the large oval, scalariformly arranged vessel/ray pits in Paradrypetes. This combination of very small intervascular pits and large scalariform vessel/ray pitting is unusual in Euphorbiaceae, but it is also present in Richeriella (tribe 10B, Phyllantheae).

\section{Tribe 1. Wielandieae Baill. ex Hurusawa}

This tribe comprises 11 genera, wood specimens were available of the genera mentioned below. VESSEL perforation plates partly or exclusively scalariform in Blotia, Heywoodia, Pentabrachium and Wielandia, exclusively simple in Astrocasia, Discocarpus, Lachnostylis and Savia. Vessel elements over $1000 \mu \mathrm{m}$ long in the genera with scalariform perforation plates (except Heywoodia), $800 \mu \mathrm{m}$ or less in the other genera.

Vessels numerous, narrow, often arranged in long radial rows, intervascular pitting and vessel/ray pitting small in all genera. PARENGHYMA diffuse or in short irregularly distributed bands one cell wide, but very scarce and restricted to some paratracheal strands in Discocarpus and completely absent in Astrocasia. RAYs more or less alike in all genera, except for the very wide and high rays in Blotia (up to $120 \mu \mathrm{m}=11$ cells wide and up to $8 \mathrm{~mm}$ high), the middle part of the rays 2-3 cells wide, usually very high, the extensions extremely high to moderately high; vertically fused rays frequent; height from 600 to $3000 \mu \mathrm{m}$. FIBRES non-septate, very thick-walled with a minute lumen (Bamber type II) in Blotia, Heywoodia, Lachnostylis, Savia and Wielandia. In Astrocasia, Discocarpus and Pentabrachium, fibres sometimes septate with thin walls; walls sometimes gelatinous; length 1300-2400 $\mu \mathrm{m}$, shorter in Astrocasia $(740 \mu \mathrm{m})$.

The taxa of this tribe show variation in structure. Blotia has the most primitive wood structure of all Euphorbiaceae as seen by the numerous bars of the scalariform perforation plates in combination with long vessel elements, long fibres with thick walls, wide and high rays, and diffuse parenchyma. Others, such as Savia and Lachnostylis, also show primitive features, but combined with more advanced characters, whereas Discocarpus, and in particular Astrocasia, seem out of place in this tribe.

According to Punt (1962) the pollen of Discocarpus represents a type of its own intermediate between that of Amanoa and that of Antidesma. Anatomically Discocarpus shows more affinities with Antidesma than with Amonoa. Punt 
commented furthermore that the pollen grains of Astrocasia are undoubtedly of the Securinega-type (a type that should now be called the Flueggea type, see Webster, 1984a). The wood structure shows affinities with Breynia of the subtribe Phyllanthoideae, but also with Andrachne of tribe Porantheroideae.

The wood structure of Pentabrachium closely resembles that of Actephila of the tribe Amanoeae.

\section{Tribe 2. Amanoeae (Pax \& Hoffm.) Webster}

Amanoa and Actephila are the only two genera of Amanoeae.

vessels with scalariform perforation plates in Actephila, simple in Amanoa; element length $(1030-) 1400(-1570) \mu \mathrm{m}$; intervascular pitting very small to minute, the vessel/ray pitting similar. PARENCHYMA in diffuse, short bands one cell wide in Amanoa, absent or restricted to a few paratracheal cells in Actephila. RAYS uniseriate and multiseriate, mostly uniseriate in Amanoa, the multiseriates 2-4 cells wide; vertically fused rays present; the type of ray cells different in the two genera, erect cells scarce in Amanoa, abundant in Actephila, in the latter genus sheath cells also present, as well as perforated ray cells with scalariform perforations. FIBRES not septate and very thick-walled, Bamber type II, in Amanoa, septate and sometimes with very thick walls, Bamber type II, sometimes with moderately thick walls and a distinct lumen in Actephila (Fig. 4), the length in both genera about $2100 \mu \mathrm{m}$.

The structure of the wood of the two genera is so markedly different from the anatomical point of view that there is no evidence to support their retention in the same tribe. Amanoa has several features in common with Savia, whereas Actephila seems closely related to Pentabrachium as mentioned before. However, it should be noted that of the 35 species of Actephila, wood samples were available only of $A$. excelsa var. javanica.

The remaining 8 tribes belong to group B, the Glochidion-type of Metcalfe \& Chalk (1950). This type is chiefly characterized by simple vessel perforation plates, absence of parenchyma (sometimes a few paratracheal strands), thinwalled septate fibres (Figs 5-8).

\section{Tribe 6. Spondiantheae Webster}

Spondianthus is the only genus of this tribe.

vessel perforation plates simple, though one vessel with scalariform perforation noted; element length on average $1090 \mu \mathrm{m}$, intravascular pitting large, c. $12 \mu \mathrm{m}$; vessel/ray pitting large and oval, or \pm circular. PARENCHYMA mostly paratracheal, scarce, as incomplete or slightly aliform rings, occasionally some diffuse strands. RAYS uniseriate and multiseriate, 5-8 cells wide and very high, up to 3-4 mm, the middle part high and composed of procumbent and square cells, the extensions not very high. FIBREs sometimes septate, walls moderately thick and lumen wide, average length $2660 \mu \mathrm{m}$.

In Metcalfe \& Chalk (1950), Spondianthus is considered as a rather problematic genus doubtfully belonging to the Euphorbiaceae. I quote: “... if it is correctly placed in the Euphorbiaceae, [it] falls into this group [Glochidion-type] on account of its septate fibres. It has the large rays typical of group $A$, the intervascular pitting is similar to that of Antidesma, and the occurrence of 

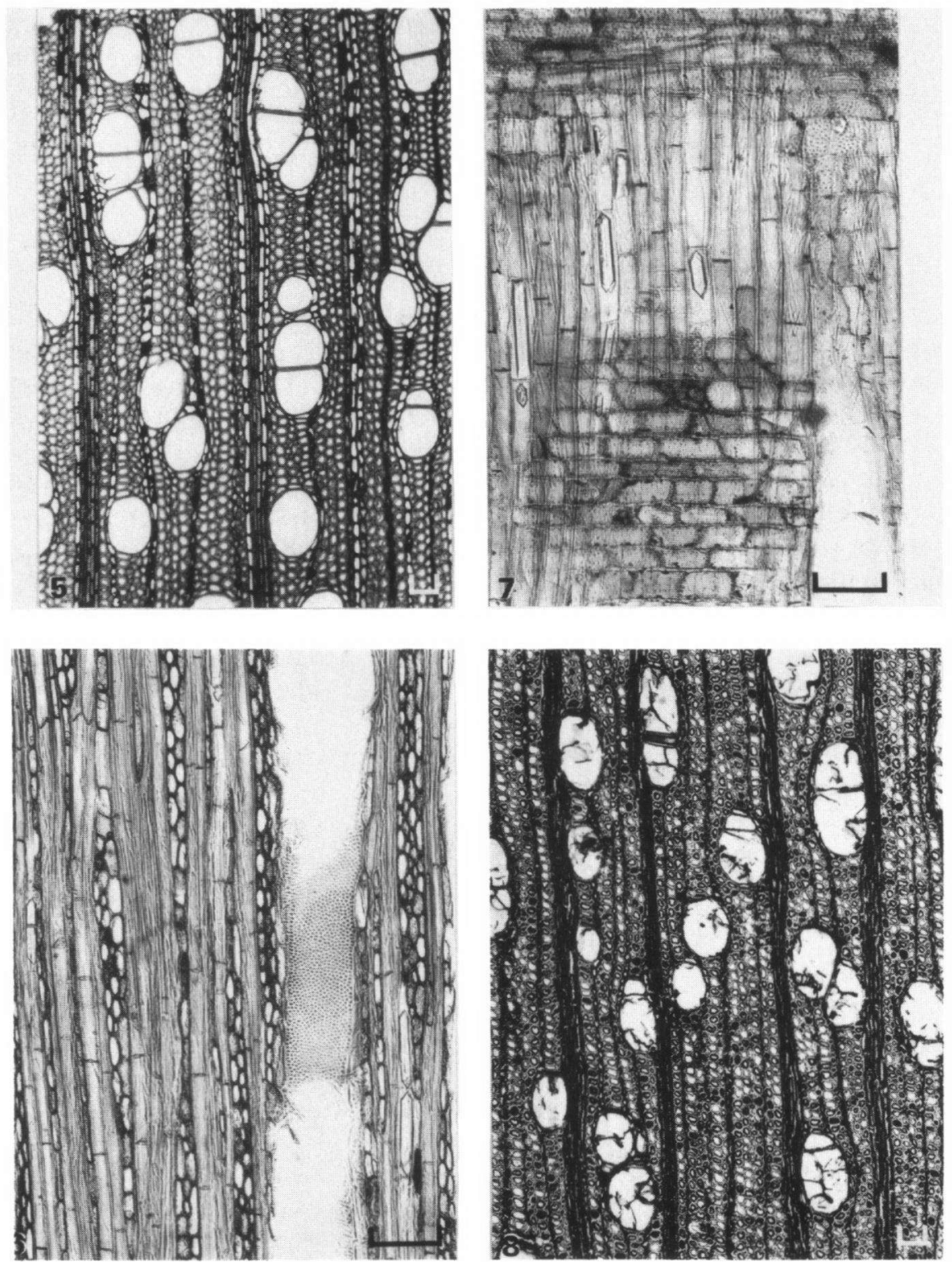

Figures 5-8. Fig. 5. Glochidion borneense cross section, parenchyma absent. Fig. 6. Tangential section of $G$. obscurum showing septate thin-walled fibres, multiseriate rays 2-3 cells wide. Fig. 7. Radial section of the same species with large elongate crystals in some of the septate fibres. Fig. 8. Crosssection of Bischofia javanica, showing resemblance to Glochidion; vessels with thin tyloses. Scale bars $=100 \mu \mathrm{m}$.

vasicentric parenchyma suggest Bridelia; only the pitting between vessels and rays cannot be matched, being large and usually circular". Having had the opportunity to see more material of groups A and B, I do not consider the vessel/ray pitting of Spondianthus so different from that of Antidesma or Phyllanthus. On account of the large rays, the long vessel elements and long fibres, this tribe seems to occupy a transitional position between groups A and B. 
Tribe 3. Bridelieae Muell. Arg.

The tribe comprises the genera Bridelia and Cleistanthus.

VESSEL perforation plates exclusively simple, mean element length $550 \mu \mathrm{m}$ in Bridelia, $1000 \mu \mathrm{m}$ in Cleistanthus; intervascular pits 5-10 $\mu \mathrm{m}$ wide, vestured in Bridelia, 2-3 $\mu \mathrm{m}$ wide in Cleistanthus, the vessel/ray pitting in Bridelia large, rounded to oval, in Cleistanthus similar to the small intervascular pits, but occasionally unilaterally compound and scalariform. PARENCHYMA scarce, paratracheal, strands of 2-8 cells. RAYs uniseriate and multiseriate, 2-6 cells wide, the middle part heterocellular with scarce truly procumbent cells, the extensions of square and erect cells, high; vertically fused rays often present; height up to $3.5 \mathrm{~mm}$, usually c. $1.5 \mathrm{~mm}$. FIBREs septate, thin- to thick-walled, often with gelatinous walls, pits small with a narrow border, restricted to the radial walls; mean length $1240 \mu \mathrm{m}$ for Bridelia, $1800 \mu \mathrm{m}$ for Cleistanthus.

Since in all taxonomic classifications Bridelia and Cleistanthus are placed together, the anatomical differences in pitting and length of vessel elements and fibres are apparently more of diagnostic importance than an indication that the genera are unrelated.

\section{Tribe 11. Hymenocardieae (Muell. Arg.) Hutch.}

Hymenocardia is the only genus in this tribe.

VESSEL perforation plates simple; element length on average $550 \mu \mathrm{m}$; intervascular pitting 5-7 $\mu \mathrm{m}$ wide, the vessel/ray pits partly \pm circular, partly large, elongate, often in scalariform arrangement. PARENGHYMA absent. RAYS uniseriate and multiseriate, 2-3 cells wide, with a very high middle portion and equally high extensions; vertically fused rays often present, height up to $3 \mathrm{~mm}$. FIBRES septate, walls moderately thick, length on average $1300 \mu \mathrm{m}$.

Hymenocardia is a taxon of controversial position within the Euphorbiaceae. Airy Shaw (1965) considered the genus as not belonging to the family, because of its winged fruit and pollen structure. He placed the genus in a separate family Hymenocardiaceae, and suggested a relationship with Urticaceae, also drawing attention to a resemblance with Holoptelea of Ulmaceae. Other authors in their treatments of African floras followed his idea of a new family, for example Radcliffe-Smith (1973) and recently Leonard \& Mosango (1985); (see also papers in this volume by Radcliffe-Smith and Webster). From the wood anatomical point of view a position in the Euphorbiaceae is not entirely unreasonable, a certain resemblance to Spondianthus exists. Metcalfe \& Chalk (1950) placed Hymenocardia somewhere near to Glochidion and Aporosella (now included in Phyllanthus), but at the same time an alliance with three tribes of the Flacourtiaceae was mentioned. From my own data and from those of Dechamps, Mosango \& Robbrecht (1985), which are in close agreement, a similarity to some genera of the tribe Casearieae (according to the treatment of Miller (1975)) is present, but discrepancies also exist. This similarity is not only true for Hymenocardia, but for several more genera with the Glochidion type of wood structure. A relationship with Urticaceae is anatomically not acceptable, and the wood of Holoptelea with its storied structure is entirely different. 


\section{Tribe 13. Bischofieae (Muell. Arg.) Hurusawa}

A monotypic tribe, comprising Bischofia (Fig. 8).

VESSEL perforation plates simple; elements on average $1040 \mu \mathrm{m}$ long; intervascular pitting large, $12 \mu \mathrm{m}$; ray/vessel pitting \pm circular and large elliptic or irregular. PARENCHYMa absent. RAYs uniseriate and multiseriate, cells wide, the middle part high, extension low to high, sheath cells often present, up to $2 \mathrm{~mm}$ high. FIBRes septate, very wide $(40 \mu \mathrm{m})$ and thin-walled, few pits on radial walls; length $2175 \mu \mathrm{m}$.

This is another genus of disputed placement in the Euphorbiaceae. Airy Shaw (1965) established the family Bischofiaceae to accommodate the genus, and suggested affinities with Staphyleaceae, a suggestion not endorsed by wood anatomy. Neither does the wood structure agree with that of genera of the subtribe Paiveusinae (subfamily Oldfieldioideae) as was pointed out by Hayden (1980). In my opinion Bischofia fits well in the Glochidion type of the Phyllanthoideae, either in a tribe of its own, or even in the subtribe Flueggeinae of the Phyllantheae.

\section{Tribe 4. Dicoelieae Hurusawa}

A monotypic tribe, comprising Dicoelia.

VESSELS with simple perforation plates, though in thin twigs some scalariform perforations present. Vessel element length on average $700 \mu \mathrm{m}$. Intervascular pitting very small, $3-4 \mu \mathrm{m}$, vessel/ray pits similar. PARENCHYMA almost absent, a few strands occasionally adjacent to vessels. RAYS uniseriate and 2-5-seriate, the latter with a high middle part and very high extensions, height up to $2 \mathrm{~mm}$; rays often vertically fused. FIBREs septate and non-septate; moderately thick-walled, minute bordered pits on radial walls; length $c .1210 \mu \mathrm{m}$.

According to Airy Shaw, this is a very isolated genus with obscure affinities. The wood structure shows resemblance to Cleistanthus.

\section{Tribe 5. Poranthereae (Muell. Arg.) Grüning}

The three genera in this tribe are subshrubs or herbs. The only material available was the woody base of a specimen of Andrachne aspera.

VESSEL perforation plates simple; element length short, $350 \mu \mathrm{m}$; intervascular pits very fine, the vessel/ray pitting similar or slightly wider, unilaterally compound. PARENCHYMa scarce, diffuse, difficult to see. RAYs uniseriate and biseriate, most cells square and erect. FIBRES non-septate, with numerous small bordered pits on radial and tangential walls; length $580 \mu \mathrm{m}$ on average.

The short vessel elements and fibres are probably related to the habit of the specimen. This habit makes interpretation of the data difficult. The absence of septate fibres makes a place amongst the tribes with Aporusa type of wood seem appropriate. The place I have given it seems doubtful.

Tribe 10. Phyllantheae Dumort.

This tribe is split into two subtribes: Securineginae and Flueggeinae. 
Subtribe 10A. Securineginae Muell. Arg.

This subtribe comprises nine genera; wood samples of Securinega, Chascotheca and Pseudolachnostylis were available.

VESSEL perforation plates simple in Securinega and Pseudolachnostylis, exclusively scalariform with 8-15 bars in Chascotheca; mean element length $c .600 \mu \mathrm{m}$ intervascular pitting very small, $2.5-4.0-6.0 \mu \mathrm{m}$, the vessel/ray pitting similar. PARENCHYMa abundant in bands 2-6 cells wide in Pseudolachnostylis, diffuse and in irregular bands one cell wide in Securinega, and absent in Chascotheca; strands of 8-12 cells. RAYs uniseriate and 2-3 cells wide, up to 5 cells wide in Pseudolachnostylis; extension low; in Chascotheca the extensions very high in Securinega moderately high; vertically fused rays frequent except in Pseudolachnostylis. FIBREs non-septate, thick-walled with small bordered pits on the radial and tangential walls in Securinega and Pseudolachnostylis; thin-walled, often with gelatinous walls, and some fibres septate, pits small, simple on the radial walls only in Chascotheca. Length on average $900 \mu \mathrm{m}$.

Chascotheca shows, like Didymocistus in Wielandieae, the same complex of characters differing from those of other members of the subtribe: scalariform perforation plates, absence of parenchyma, and partly septate fibres. Securinega and Pseudolachnostylis do not comply with the general aspect of the Glochidion type of wood structure by their variable amounts of parenchyma and the absence of septate fibres, features characteristic for the Aporusa type. In fact, Metcalfe \& Chalk (1950) cited the wood of Lingelsheimia, another genus of this subtribe (not investigated here), as resembling Drypetes in group A, which also applies for the two genera Securinega and Pseudolachnostylis.

\section{Subtribe 10 B. Flueggeinae Muell. Arg.}

A large taxon comprising Breynia, Flueggea, Glochidion (Figs 5-7), Margaritaria, Phyllanthus, Richeriella, Sauropus and two more genera of which no wood was available. Neowawrea, incorporated in Drypeteae, should be included in this subtribe, as already mentioned.

VESSEL perforation plates exclusively simple; mean vessel element length $720 \mu \mathrm{m}$; intervascular pits medium-sized, 5-8 $\mu \mathrm{m}$, except in Breynia and Sauropus where pits very small; the vessel/ray pitting large, \pm circular or, often, narrow, oval, arranged in horizontal rows, again with the exception of Breynia and Sauropus with pitting similar to the intervascular pits. PARENCHYMA absent, or very scarce to scanty, paratracheal as a few strands adjacent to a vessel, strands of 2-8-10 cells. RAYs uniseriate and multiseriate, 2-3 cells wide (much wider in Phyllanthus emblica), the middle part not very high, composed of square and relatively short procumbent cells, extensions very high to high; vertically fused rays often present; total height from 1.5 to $4.5 \mathrm{~mm}$, higher in Phyllanthus emblica. FIBRES septate, walls generally thin, but often gelatinous, small pits restricted to the radial walls; length on average $1340 \mu \mathrm{m}$.

The wood structure of the subtribe is remarkably uniform, except for the very small pits in Breynia and Sauropus. These two genera show a great similarity, which is in accordance with the remark of Airy Shaw (1975) in his treatment of the Euphorbiaceae of Borneo, that Breynia, Sauropus and Synostemon are scarcely distinct genera. Metcalfe \& Chalk (1950) treat Breynia in the group of "other 
genera", but their description is entirely different from the wood structure of the three specimens of various species seen by me; the discrepancy is most probably due to incorrectly identified material.

Until recently much confusion existed between wood samples assigned either to Securinega or Flueggea. From the foregoing descriptions it will be evident that these taxa are far more different in their wood structure than any of the genera of the subtribe Flueggeinae are among themselves. Webster (1984a), in his revision of Flueggea, has straightened out this confusing state. Securinega is now restricted to four species, three from Madagascar and one from Mauritius, all showing the same type of wood structure.

\section{Tribe 12. Uapaceae (Muell. Arg.) Hutch.}

A monotypic tribe of doubtful position, considered by Airy Shaw (1965) as belonging in a separate family having affinities with Anacardiaceae and Picrodendraceae.

vESSELS with simple perforation plates, though Normand (1955) mentioned an occasional scalariform perforation; element length $c .750 \mu \mathrm{m}$; intervascular pits $10 \mu \mathrm{m}$, vessel/ray pitting large elliptic and smaller roundish. PARENCHYMA paratracheal as incomplete rings, also in short bands and diffuse; strands of 4-6 cells. RAYs uniseriate and multiseriate, $3-6$ cells wide, the middle part very high and heterocellular, the extensions also very high; rays often vertically fused; height $3.5-5 \mathrm{~mm}$. FIBREs thick-walled, non-septate, simple pits restricted to the radial walls; mean length $1900 \mu \mathrm{m}$.

The wood structure is in several respects unusual for the Euphorbiaceae. Metcalfe \& Chalk (1950) place Uapaca with the group "other genera", which comprises mainly the Oldfieldioideae. From a comparison of the wood structure of Uapaca with the data published by Hayden (1980) for the genera in the subfamily Oldfieldioideae no close affinities between the taxa are apparent. Giraud (1983) lists in her thesis a number of genera according to an evolutionary scala. In this list Uapaca is placed next to Drypetes and near to Hieronyma. The three genera have indeed some features in common, but I would hesitate to assign Uapaca to either Drypeteae or Antidesmeae.

\section{CONCLUSIONS}

Conclusions concerning the composition of the tribes have already been given, and the results are summarized in Table 1 . It is apparent that the sequence of the tribes in Webster's classification, as indicated by the numbers of the tribes, is quite different from the sequence obtained when anatomical characters are used exclusively for classification. The author is well aware that the data of wood anatomy have to be interpreted together with data from other disciplines, but she considers it helpful to present the anatomical information as a tool for a definitive classification. Results in the past, such as the settling of marked anatomical differences noticed among species of Flueggea and Securinega by Webster's revision of Flueggea (Webster, 1984a), which brought uniformity to specimens previously described as belonging to either one genus or the other, strengthen the wood anatomist in the believe that wood structure can offer a positive contribution to classification. 
The sequence of the tribes with woods of the Aporusa type has a sounder base than the sequence in the other group. This is mainly due to the fact that in the Aporusa type, anatomical characters, well-established as indicating a primitive or more advanced state, are present, whereas such characters are less obvious in the taxa with the Glochidion type of wood. Furthermore, the tribes or taxa are much more alike, and distinctions are not clear.

The position of Poranthereae is dubious, partly because material was not adequate, but also because the wood characters are intermediate between the Aporusa and Glochidion groups. This is also the case for the genera Antidesma, Astrocasia, Didymocistus, Discocarpus and Jablonskia, genera in which some of the fibres are septate and in which parenchyma is absent. The two last-mentioned genera also possess some vessels with scalariform perforation plates.

Tentatively Antidesma might be placed in a tribe by itself amongst the tribes with Glochidion wood, or in a family of its own as advocated by Airy Shaw (1965) who re-established the family Stilaginaceae. Astrocasia might be related to Andrachne, but lack of reliable material of the latter genus prevents a definite judgment. Jablonskia, a genus established by Webster (1984b), was provisionally placed by him somewhere near to Phyllantheae, subtribe Securineginae. In wood characters it shows more affinities with genera of the Aporusa group, but it does not fit in any of the tribes (Mennega, 1984).

The wood of Uapaca is in several respects different from that of the Euphorbiaceae. Perhaps this taxon might better be assigned to a family Uapacaceae in conformity with Airy Shaw's suggestion (Airy Shaw, 1965). Comments on the taxonomic position of Uapaca, as well as Hymenocardia and Bischofia, will be found in the papers by Radcliffe-Smith and by Webster in this volume.

Genera not listed by Webster (1975) are Martretia and Paradrypetes. Martretia fits remarkably well in the tribe Aporuseae, a position corresponding to the place next to Aporusa in Pax \& Hoffman (1931).

Paradrypetes resembles Drypetes very closely in structure, as is apparent from the description of Matos Araujo \& Mattos Filho (1984), except for a different type of vessel/ray pitting. Accordingly, I have included the genus in the tribe Drypeteae.

\section{ACKNOWLEDGEMENTS}

I am greatly indebted to Miss Mary Gregory and to Dr D. F. Cutler for reading and carefully correcting the preliminary manuscript, and for their helpful comments.

\section{REFERENCES}

AIRY SHAW, H. K., 1965. Diagnoses of new families, new names etc., for the seventh edition of Willis's 'Dictionary'. Kew Bulletin, 18: 249-273.

AIRY SHAW, H. K., 1975. The Euphorbiaceae of Borneo. London: H.M.S.O.

BAMBER, R. K., 1974. Fibre types in wood of Euphorbiaceae. Australian Journal of Botany, 22: 629-634.

CHALK, L., 1983. Wood anatomy, phylogeny, and taxonomy. In C. R. Metcalfe \& L. Chalk (Eds), Anatomy of the Dicotyledons, 2nd edition, 2: 108-125. Oxford: Clarendon Press.

DECHAMPS, R., MOSANGO, M. \& ROBBRECHT, E., 1985. Etudes systématiques sur les Hymenocardiaceae d'Afrique: la morphologie du pollen et l'anatomie du bois. Bulletin du Jardin Botanique National de Belgique, 55: 473-485. 
GIRAUD, B., 1983. 'Xylologie et Phylogénie des Euphorbiacées arborescentes.' Thèse de Doctorat d'Etat à I'Université Pierre et Marie Curie, Paris.

HAYDEN, W. J., 1980. 'Systematic Anatomy of Oldfieldioideae.' Ph.D. Thesis, University of Maryland.

HAYDEN, W. J. \& BRANDT, D. 1984. Wood anatomy and relationships of Neowawrea (Euphorbiaceae). Systematic Botany, 9: 458-466.

HUTCHINSON, J., 1969. Tribalism in the family Euphorbiaceae. American Joumal of Botany, 56: 738-758.

LEONARD, J. \& MOSANGO, M., 1985. Hymenocardiaceae. In Bamps, P. (Ed.) Flore d'Afrique Centrale: 1-16. Bruxelles: Jardin Botanique National de Belgique.

MATOS ARAUJO, P. A. \& MATTOS FILHO, A. de., 1984. Estrutura das madeiras brasileiras de Dicotiledôneas. XXVI. Euphorbiaceae. Rodriguesia, 36 (59): 25-40.

MENNEGA, A. M. W., 1984. Wood structure of Jablonskia congesta (Euphorbiaceae). Systematic Botany, 9: 236-239.

METGALFE, C. R. \& CHALK, L., 1950. Anatomy of the Dicotyledons. Oxford: Clarendon Press.

MILANEZ, F. R., 1935. Anatomia de Paradrypetes ilicifolia. Arquivos do Instituto de Biologia Vegetal. Rio de Janeiro, 2: $133-156$.

MILLER, R. 1975. Systematic anatomy of the xylem and comments on the relationships of Flacourtiaceae. Joumal of the Amold Arboretum, 56: 20-102.

NORMAND, D., 1955. Allas des bois de la Cóte d'lvoire, 2. Nogent-sur-Marne, France: Centre Technique Forestier Tropical.

PAX, F. \& HOFFMAN, K., 1931. Euphorbiaceae. In A. Engler, Die natülichen Pfanzenfamilien, Band 19c: 11-233. Leipzig: W. Engelmann.

PUNT, W., 1962. Pollen morphology of the Euphorbiaceae with special reference to taxonomy. Wentia, 7 : $1-116$.

RADCLIFFE-SMITH, A., 1973. A new variety of Hymenocardia acida (Hymenocardiaceae) In F. N. Hepper (Ed.), Tropical African plants: XXXIII. Kew Bulletin, 28: 319-326.

WEBSTER, G. L., 1975. Conspectus of a new classification of the Euphorbiaceae. Taxon, 24: 593-601.

WEBSTER, G. L., 1984a. A revision of Flueggea (Euphorbiaceae). Allertonia, 3: 259-312.

WEBSTER, G. L., 1984b. Jablonskia, A new genus of Euphorbiaceae from South America. Systematic Botany, 9: 229-235. 